\title{
道路容量からみた東京都区部の都市構造の事後評価に関する研究 An Evaluation of Urban Structure in Tokyo Wards in terms of road capacity
}

吉田 真紀*, 森本 章倫**, 古池 弘隆*** By Maki Yoshita, Akinori Morimoto and Hirotaka Koike

\section{1.はじめに}

近年，モータリゼーションの進展により様々な交通問 題を引き起こしているが，とりわけ都心部における慢性 的な「交通渋滞」は深刻な問題を抱えている.

この原因を都市計画において密接な関倸とされる交通 と土地利用の両政策から考えてみると，時代背景ととも にその関倸の改善が泊られているのがれかる。これまで は, 自動車の増加と共に道路整備や交通施設の増加を図 万需要対応型の交通計画が中心であった.しかし近年, 道路延長の伸びよりも自動車台数の伸びが遙かに上回り， これまでのように交通インフラ整備だけで渋滞を緩和さ せることは困難であると考えられるようになってきた. こういった問題に対して，既存の交通体系を前提に，道 路容量を超えないように，交通需要そのものをコントロ 一ル寸万交通需要管理政策（TDM）や，都市成長管理政 策少注目され，それに関寸る研究も増えてきている.

交通と土地利用の相互関連性を探求した研究は 1960 年 代から急速に增えはじめた. Giuliano(1989) ${ }^{1)}$ は，これら を Alonso(1964) に代表される経済的アブローチと， Herbert and Stevens(1960) らをはじぬ)とする数的モデリン グの） 2 つに分類している. 一方, Lowry(1964) らが提案 した統合化モデルの流れは, ISGLUTI(1988)2) に代表され るように多くの実用的モデルを提案してきた。 これらは より複雑な都市状況の再現を試みてきたが，肥大化する モデルの汎用性も実用上の問題としてつきまとった.こ れ、に対して，一面的ではあるが都市現象の一部に焦点 を当てることで，問題解決の系口を探る研究も見られる 上うになった．例えば，交通容量という面からの容積率 規制に関寸石研究として，道路ネットワーク容量に着目 して容積率の設定方法について言及した柏谷・朝倉・矢 島(1996) $)^{31}$ らや，交通施設の容量を鑑み，500m メッシュ 単位で適正容積率を推計した森本・中川(1992) 出) らがある. また, 中条・山川・秋山(1998) 5 らは, 都心 8 区を対象に 発生集中交通量を用いて面交通量の推計のもと，現実と の乘離量をグロス容積率によって定量的に示している.

一方，都市構造を定量的に分析評価し，将来に対寸る

Key Words : 都市計画，土地利用，交通容量

*学生会員 宇都宮大学大学院工学研究科建設学専攻

( 个321-8585 栃木県宇都宮市陽東 7-1-2

TEL:(028-689-6224, FAX:028-689-6230)

**正会員 工博 宇都宮大学工学部

***ーフェロー会員 Ph.D. 宇都宮大学工学部
望ましい都市構造を明らかにする事を目的とした研究と して西宮・中村・佐々木(1983) ら) らが挙げられる。 また， 川上(1986) は東京市街地における都市機能の集約と都 市構造の動向を把握した上で，一極集中型都市における 集積抑制及び副都心と核都市の育成策等の政策を吟味し ている. そこで，これらの政策の基本的諸概念が持の心゙ き内容と果たすべき機能が時代と共に変杖ていながら， 事実に即した検討をしていないことが問題であるとして いる. そこで, 牛田(1989) $)^{8)}$ は, 一極集中が及!゙寸地価高 騰ぶ交通混雑などの弊害を引き起こしている一極集中構 造を解明し，分散型政策の都市構造において，実際にシ ミュレーションを行い定量的に評価を行っている．また 近年では，環境負荷の小さい都市構造及び交通体系走研 究した小根山・大西(1997) ら) らや, エネルギー削减量ふら みた望ましい都市構造としてどのような人口分布が良い か検討を行った杉田・鹿島・谷下・高嶋(1998) ${ }^{1011}$ らが挙 げられる.しかし，交通面において望ましい都市構造を 推計し, 都市政策との対比を行っているものは少ない.

本研究では現在の道路容量または道路ネットワークか ら交通渋滞の発生しない都市構造を算出し，これまで土 地利用政策のなかで，交通の観点において目指兰うとし てきた都市構造と適切に対応しているのか坴比較・評価 寸ることを目的とする．具体的に交通行動特性は東京都 市圈を対象として，道路容量を制約とした交通／土地利 用モデルを構筑することで，適正な都市構造分布を東京 都区部で推計する．また土地利用政策に関しては広域的 には首都圈整備基本計画，そして狭域的には東京都長期 計画の経緯から都市構造の在り方を顧みる. その上で推 計値と東京の土地利用政策の比較を行うことで, 道路容 量から見た適正な都市構造について言及寸る.

\section{2. 東京の都市政策の変遷}

\section{（1）首都圈整備基本計画の目指す都市構造}

ここでは，主に首都圈整備基本計画または東京都長期 計画を振り返ることで，計画策定時の背景を探るととも に，その計画の方向性を探る.

第 1 次首都圈整備基本計画(1958)では, 政治・経済・文 化の中心地として東京が位置づけられ，東京への過度の 集中抑制に主眼がおかれた。整備の特徴としては都市ひ 肥大化を抑制するグリーンベルト（近郊地帯）の構想汴 挙げられる (図 1). 


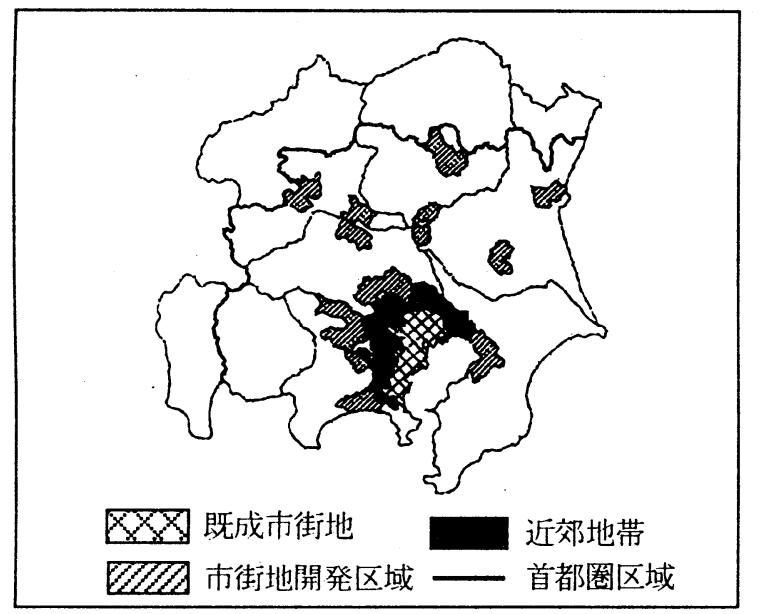

図 1 第 1 次首都圈基本計画（1958）11

このように，都心部への過度の集中を抑制し，これを 他の地域に分散寸るという考え方は 1950 年代から，一貫 した東京の都市べくりの基本であった．その考えを引き 継ぐかのように，東京都長期計画（1963）では新宿・渋 谷・池袋を副都心として位置づけ，多心型都市構造八の 途を開いた．しかし，グリーンベルトの崩壊に伴い，第 2 次首都圈整備基本計画（1968）では，第 1 次計画の全面 改定を行い，大都市への集中をある程度容認寸るといっ た現状追認型の軌道修正が行执た．第 3 次首都圈整備 基本計画（1976）では，肥大化する都市機能を首都圈全 体にネットワーク化を図ることで解決しようとしている.

これまでの傾向をみると，東京の開発需要の急激な増 大に対して，一定のエリアに都市を囲い込む土地利用制 限ふら，交通施設の増強や核都市育成といった広域化， 連帯化によって集中問題を解決する方針へ主眼が移って きたといえる.また，1982 年の東京都長期計画では，副 都心の青成から，さらに発展した多心型構造論が展開さ れた。 これは，東京の諸機能を「心」という概念をもつ て体系的に整理したものであり，1950 年代のような都心 機能（業務管理機能）の分散立地だけに着目することな く，それを通じて職と住のバランスのとれた都市の゙くり を強調している.

その後さらに，第 4 次首都圈整備基本計画（1986）で は，21 世紀の到来を踏まえた上での第 3 次計画の継承と いうぶきものとなっている，特徵としては，多核多圈域 型都市構造を形成寸るため, 業務管理機能などの誘導地 の受け皿として，業務核都市および副次核都市の重点的 整備を掲げていることである(図 2).

このように東京の都市構造の変遷をみると,グリーン ベルトによる囲い込みの失敗を経て，より広域に都市機 能を展開し，多極化を図ることで世界に類をみない巨大 都市を維持しようとしていることが伺える. 特に副都心， 業務核都市，副次核都市といった重層構造を有寸る多核 多圈域型の地域構造を形成寸ることで，東京大都市圈の 再構築を目指した.

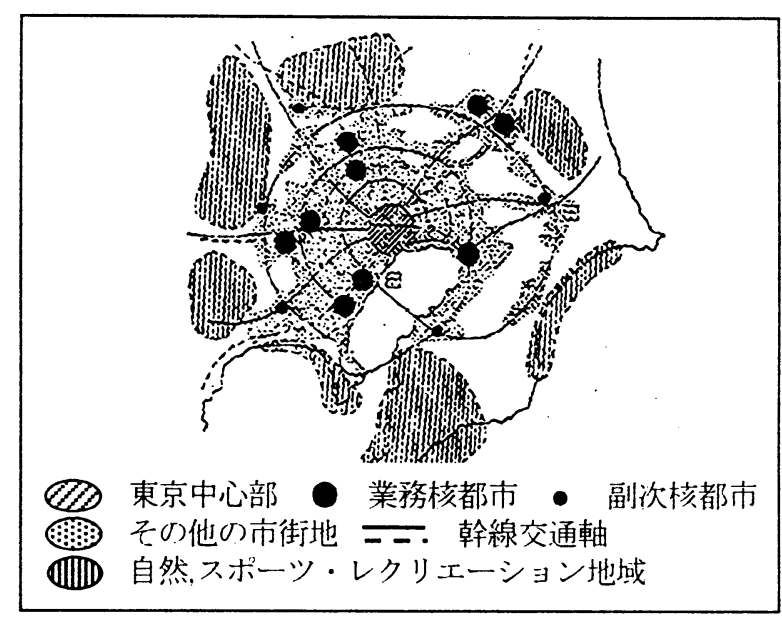

図 2 首都改造計画（1985） ${ }^{121}$

\section{（2）東京の土地利用政策}

これまで広域的な視点からは首都圈整備基本計画党用 い，狭域的には東京都長期計画によって，東京ひ計画理 念をたどってきた．次に，計画理念を実際の計画行政に おとし，土地利用を誘導する制度として容積率制に着目 する．まず，東京都における容積率の変遷をたどり，ま た道路容量との関連性の考慮がされているのかを検証す る.

容積率規制が導入される以前は，市街地建築物法に端 を発寸る「絶対高さ制限」であった。戦後，容積率䙺制 の必要性が高まることになったが，その原因としていい くつかの理由があった，それは，人口・産業の集中によ る地価の上昇や，自動車の普及によるオーブンスベース の必要性，建築技術として高層建留物が建てられらよう になったことなどが挙げられる。このような背景から容 積率制度は, 不合理な高度制限に代狂って, 1963 年 (昭 和 38 年）改正の建築基準法に採り入れられた。

東京都の)容積率制度は 1964 年（昭和 39 年）に環状六 号線以内の容積地区を指定し，1968 年 2 月に環状六号線 外の指定を行っている.

環状内の容積率の指定に当たっては，堀内 ${ }^{131}$ によると， 業務地区では道路交通量と建筑物容積が均衡を保つ上う に配慮し, 住宅地では大量輸送機関による輸送力と建筑 物容積の均衡を保っことを目標としている. しかし，提 案された容積率は当時の容積限界（高さ×建坪率）と著 しくかけ離れることがなく、また現存した建物の容積率 とも遊離しないことを主として考慮したものであった。 そのため, 比較的高い容積率が提案されている.

環状六号線外の容積地区の指定に当たっては，未整備 な間は容積率を低く定め, 整備された時点で高い容積率 に変更することを考えていた．しかし害際には，現存す る建筑物の容積率を考慮して高い容積率を指定せざる在 得ず，その容積率は都市施設オ゙既に整備されたものとし て指定される状態であった.このように，東京に揦ける 容積率指定の経緯を振り返ると, 交通とのバランス在図 ろうとする試みはあったものの, 結局は現況追認型を余 
儀なくされたことが伺える.

次に，当初の指定から近年に至るまでの東京の容積率 指定の)経緯学見る（表 1).

表 1 都区部の容積率別の指定面積（ha）

\begin{tabular}{|c|c|c|c|c|}
\hline $\begin{array}{c}\text { 指定 } \\
\text { 容樍率 }\end{array}$ & 1970) 年 & 1973 年 & 1981 年 & 1990 年 \\
\hline $1.000 \%$ & 135 & 114 & 114 & 114 \\
\hline $900 \%$ & 114 & 90 & 87 & 87 \\
\hline $800 \%$ & 303 & 404 & 405 & $7 \quad 428$ \\
\hline $700 \%$ & 912 & 752 & $\begin{array}{l}727 \\
\end{array}$ & 748 \\
\hline $600 \%$ & 1,570 & 1,373 & 1,360 & 1,447 \\
\hline $500 \%$ & 2.871 & 2,139 & 2,177 & 2,402 \\
\hline $400 \%$ & 4,189 & 2,895 & 3,416 & 33,920 \\
\hline 計 & 10.094 & 7,767 & 8,286 & 9,146 \\
\hline
\end{tabular}

出典 : 東京都都市計画概要 $(400 \%$ 以上対象)

注 : $1,000 \% \% \sim 500 \%$ は商業地域

$400 \%$ は商業・近隣商業・住居・隻工業・工業地域を含む

1970 年 (昭和 45 年)に建築基準法の全面改正が行犼， 1972 年に用途地域の指定基準の見直し，1973 年に用途地 域の指定の見直しが行われた. 表1か心，1970 年の旧指 定から 1973 年の新指定一の比較をすると $800 \%$ を除き $400 \%$ 以上の高容積地区の減少が目立つ.つまり，この時 期に当初高く設定された容積率をダウンゾーニングさせ, 理想に近一うたたといえる. しかし，その後の指定の変化 を見ると，900\%，1,000\%の超高層地区の指定は変和らな (ものの)，4(0)\%以上の高容積地区の指定は暫増している. 特に之の傾向は $400 \%$ \% 600\%の指定の地区が顕著で, 都 市全体の中高層化が伺える。

\section{3. 交通 /土地利用モデルの構築}

\section{（1）モデルの概念}

首都圈整備基本計画などにみられる東京の多心型都市 ー゙くりは，慢性的な交通渋滞を解消寸るのであろうか。 現実には，計画で揭げられた都市機能および交通ネット ワークガ十分に機能していないため, 都心部における「交 通涉滞」などの問題が発生している. これは交通施設整 備が都市成長速度に追いつかなかったことにも起因寸る が，過大な都市成長を容認した容積率制度にも問題があ る.

本研究では, 東京都市圈の広域の交通行動を前提に, ゾーン間で集計道路ネットワークを組むことで，都区部 ひ適正容積率を区単位に推計寸る.なお推計フローを図 3 に示寸.

このモデルは，東京都市圈を対象とした交通需要予測 モデルと, 東京都区部の適正容積率推計モデルの 2 つか ら構成されている. 交通需要予測では, 東京都区部の中 ゾーン (23ゾーン) に加えて, 東京都市圈大ゾーン (45
ゾーン) からなる 68 ゾーンにおいて，平成 6 年度道路交 通センサスをもとに隣接ゾーンを結んだ集計ネットワー ク（有向 310 リンク）からなっている. ただし，今回は 一般道路と高速道路との区別は行っておらず，総体的な 道路容量をもとに集計を行っていることに注意が必要で ある. そして，そのネットワーク上で四段階推定法を用 い，リンク交通量を推計し影響行列を作成寸る．次に， 適正容積率推計モデルでは, 先の 310 リンクの中で対象 地域である東京都区部（23ゾーン）とそれに隣接寸る大 ゾーン (8 ゾーン) を結ぶ集計ネットワーク（有向 118 リンク）を取り出し，各リンクの交通容量を制約として, シンブレックス法を用いて自動車最大発生交通量を求ぬ る。これを床面積原単位から容積率に变換して，交通混 雑の発生しない都市構造を推計する.

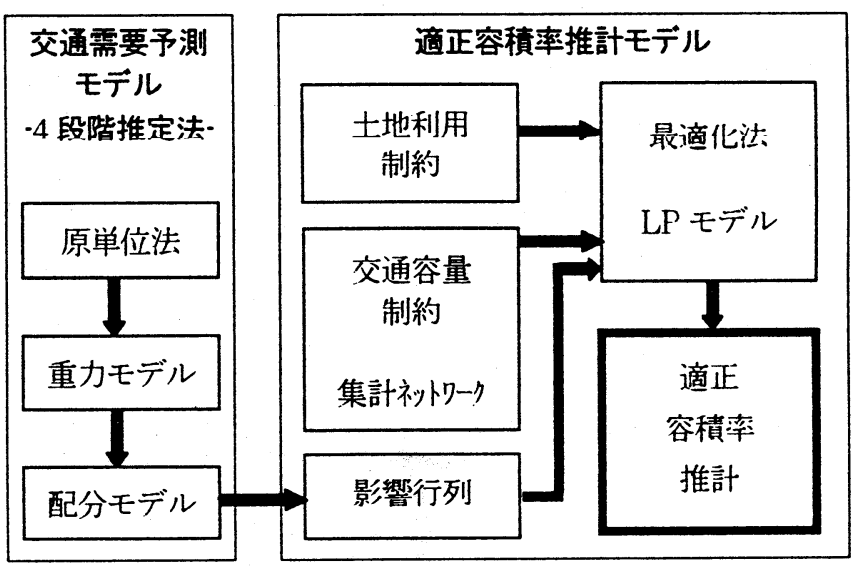

図 3 交通/土地利用モデルフロー

\section{（2）交通需要予測モデルの構筑}

都市構造の変動に伴う交通の変化を捉えるために，四 段階推定法により交通需要予測モデルを構築する. 分析 対象エリアは東京都市圏であり, 平成 5 年東京都市圈パ ーソントリッフ調查を使用した. 68 ノード×310 リンク の集計ネットワーク上で推計寸る. なお，交通目的とし ては全目的とする. 次に, 四段階推定法による各モデル を順に述べる.

\section{（a）発生，集中及び分布交通量の推計}

発生・集中量の推計は原単位法を用いて，区部内外で それぞれ異なる 2 つのモデルを構筑する. 区部内の発生 集中交通量予測には，土地利用変動に対応寸るため゙，用 途別床面積を変数としたモデル（中ゾーン推計）を構筑 する，一方で，区部外は交通需要量の予測のみで良いた め, 夜間及び従業人口を用いてモデル（大ゾーン推計） を構築した。

分析の結果, 相関係数は概少高い值を示しており，信 頼性の高い式を構築できたといえる.

$\begin{array}{lll}\text { 区部発生量： } & O(m)=\sum a k \cdot F k(m) & (R=0.95) \\ \text { 区部外 " } & O(m)=a p \cdot P n(m) & (R=0.94) \\ \text { 区部集中量： } & D(m)=\sum a k \cdot F k(m) & (R=0.92) \\ \text { 区部外 " } & D(m)=a p \cdot P w(m) & (R=0.89)\end{array}$




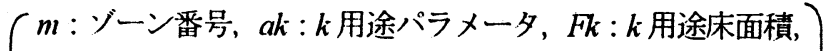
$k$ : 業務, 商業, 住宅, $a p:$ パラメータ, $P n:$ 夜間人口,
$P u^{\prime}$ :従業人口

次に分布交通量の推計には，以下の重力モデルを用い て推計寸る.

$$
T Z_{m n}=\frac{k O(m)^{\alpha} \cdot D(m)^{\beta}}{G(m, n)^{\gamma}} \quad(R=0.83)
$$

$\left(\begin{array}{l}T Z_{m,}: \text { 分布交通量, } G(m, n): m, n \text { ゾーン間平均トリッブ長, } \\ k, a, \beta, \gamma: \text { バラメータ }\end{array}\right]$

(b) 配分交通量の推計

一般的に交通量配分モデルには大きく均衡型配分と非 均衡型配分に分類される.ここではこの 2 つ配分方法 を試みた。 まず非均衡型配分であるが，最短経路探索で 女る Dijkstra 法をもとに多経路配分モデルである Dial モ デルを用いて配分を行った，そのモデルの中には，交通 容量を考慮した混雑回避の概念を組み込んでいる. 次に, より人間の交通行動に基づいた均衡型配分で推計を行っ た.

結果的に配分交通量と実測の集計交通量との相関係数 を両配分方法で比較したところ, 非均衡型である Dial モ デルの $\mathrm{R}=(0.65 よ り も$ ，均衡型配分の $\mathrm{R}=0.89$ の)方が高い 信頼性の女る結果を得た。具体的に用いた均衡配分は, 利用者均衡配分の中でも起終点間の需要交通量が固定で ある場合に用いられる需要固定型均衡配分を用いた。均 衡配分は数理最適化問題として下記のように定式化され 万。

$$
\begin{array}{lr}
\min : & F=\sum_{a} \int_{0}^{q_{a}} t_{a}(q) d q \\
\operatorname{S.T}\left\{\begin{array}{lr}
q_{a}=\sum_{i j} \sum_{k} \delta_{i j k a} h_{i j k} & \\
\sum_{k} h_{i j}=T_{i j} & \forall a \\
h_{i j k} \geq 0 & \forall i, j, k
\end{array}\right.
\end{array}
$$

$\left[\begin{array}{c}q_{a} \text { : リンク } a \text { のリンク交通量, } h_{i j k}: i, j \text { OD ペア間 } \\ \text { 第 } k \text { 番目経路交通量, } T_{i j}: i, j \text { OD ペア間交通量, } \\ \delta_{i j k a}: \text { リンク } a \text { O } i, j \text { OD ペア間第 } k \text { 経路選択可能性, } \\ t_{a}(q) \quad: \text { リンクコスト関数 }\end{array}\right.$

な打，配分アルゴリズムには Frank-Wolfe 法を用いる. ネットワーク上における各リンクはそのリンク特有の抵 抗を持つ. 抵抗を構成する要因には旅行時間, 走行時間,

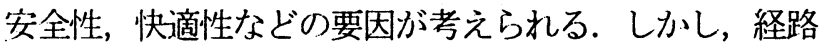
選択行動に影響を与える主な要因は所要時間であると考 えられることわら，交通量配分問題においては所要時間 がリンク抵抗の単一の測度として用いられる場合が多い.

本研究では，この走行時間関数に均衡配分に打いて操 作性の高さォ江一般的に用いられている BPR 関数を使用 寸る. BPR 関数は下記のような形をとる. なお，データ 仕平成 6 年道路交通センサスを用い，日単位のリンクコ ス卜関数バラメータは溝上 ${ }^{14)}$ らにより提案されている $\alpha=0.96, \beta=1.20$ を使用寸る.

$$
\begin{gathered}
t_{a}\left(q_{a}\right)=t_{a(1)}\left\{1+\alpha\left(q_{a} / q_{a 0}\right)^{\beta}\right\} \\
\left(\begin{array}{l}
\left.q_{a}: \text { リンク } a \sigma\right) \text { リンク交通量, } q_{a 0}: \text { 道路容早 } \\
t_{a 0}: \text { ゼロフロー時所要時間 }
\end{array}\right]
\end{gathered}
$$

\section{（3）適正容積率推計モデルの構筑}

(a) 影響行列の作成

影響行列とは，m ゾーンで発生した交通量ぶ e リンク に入る確率を要素としてもつ行列である.この行列は対 象地域の総ゾーンが $\mathrm{n}$, 総リンク数が $\mathrm{k}$ の場合, $\mathrm{n} \times \mathrm{k}$ の 次元をもつ. 本研究では, 総ゾーン数は区部内 $の$ 中ゾー ンの 23 である. また，総リンク数は区部内とそれいに粼教 才る 8 つ大 大ゾーンを対象に，隣接寸るゾーン同士をり ンクで結んでいくと 118 リンクある。 したがって，68x 118 の影響行列ができる. その算出式を以下に示寸.

$$
V^{\prime m}\left(e_{i j}\right)=\frac{T^{m}\left(e_{i j}\right)}{\sum_{n} T Z_{m n}}
$$

$\left(\begin{array}{l}V^{m}\left(e_{i j}\right): \text { 影響行列, } T^{m}\left(e_{i j}\right): m \text { ゾーンが発生した交通量で } \\ \text { リンク } c_{i j} \text { に配分された交通量 (台) }{ }_{n} \Sigma T Z_{m, n}: m \text { ソーンン } \\ \text { から発生した交通量, }\end{array}\right.$

(b) 最適化法

ネットワークの物理容量として，固定したリンクの容 量を与えた場合の最大 OD フローを考える.このアフロ 一チとして，LPモデルを用い，シンプレックス法により 23 区内の最大発生交通量を求める。デー夕は平成6 年度 の道路交通センサスを用いており，制約条件となる交通 容量Uについては，隣接するゾーン間にまたぶるセンサ ス道路に打いて，12 時間交通量をまとめた集計リンク交 通量で表現寸る.

$$
\begin{gathered}
\text { 制約条件 } \quad \sum_{j=1}^{n} V\left(e_{i j}\right) \cdot X_{j} \leq U_{i} \quad(i=1,2, \cdots, m) \\
X_{j} \geq 0 \quad(j=1,2, \cdots, n) \\
\text { 目的関数 } \quad \max Z(X)=\sum_{j=1}^{n} X_{j} \\
\left(\begin{array}{c}
V(e): \text { 影響行列, } X: \text { 最大自動車発生交通量 (古/12h) }) \\
U: \text { 道路容量 (台/12h) }
\end{array}\right)
\end{gathered}
$$

（c）容積率の算出

算出された中ゾーン単位での自動車最大発生交通量で は，一概に各ゾーン間で比較できないため下記の式によ り容積率八と換算する。ここで発生・集中交通量で推計 した各用途のバラメータを用い，平均乗車率 $1.31^{151}$ を乗 ずる. 各用途は各ゾーンにおける現状の用途割合を用い ている.これにより，現在の用途特性を捉えつつ，容積 率に換算していることとなる.

$$
F_{m}=1.31 \sum_{k} a_{m}^{k} \cdot X_{m} / G_{m}
$$

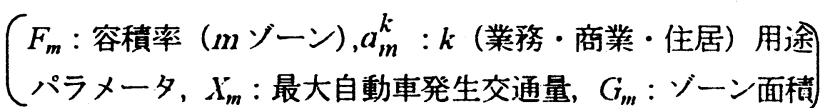


ここで本来の交通／土地利用モデルならば，推計して 得られた都才構造により交通発生パターンが変化し，そ れによって都柿構造がさらに変化するといった，双方向 的な分析が必要となる. またその際には，土地利用用途 の変更も，考虑し，グラビティのパラメータも再考する必 要があり，モデルとしてかなり大規模なものとなる. 本 研究では，現在の交通行動・交通ネットワークを前提と した場合の都市構造の推計を行うことを目的としている ため，本来の交通／土地利用モデルを簡略化し，交通か ら土地利用を求める一方向の分析にとどめている. なお， 交通小心みた望ましい都市構造の推計には，今回の自動 車のみならず，大量輸送機関である鉄道も含ぬたより詳 細な推計が必要で女る。

\section{4. 東京23区におけるシミュレーション}

第 3 章で構筑したモデルを用いることで, 現状の道路 施設に対応した区部の容積率分布を示寸，具体的には， 区部内心道路交通施設を最大限に使って，区部内で発生 集中寸る交通量を最大にする。つまり，それにより区部 全体の都市容量の最大化を目指寸こととなる．交通混雑 緩和を目指した都市構造とはいったいどのような分布な のか, 計画とシミュレーション結果とを比較することで, 計画の事後評価を行う。

\section{（1）現在の都市構造}

ここ10)年間に扑ける東京都市圈の交通特性をみると, 区部内において人口の伸び，総交通量等は鈍化の傾向が みられるが，区部外においては自動車分担や地域間トリ ッブひ增加が顕著である。 また東京都市圈におうける地域 間交通では，依然として区部に出発地または到着地を持 つトリッブが多いが，区部外の隣接寸る地域間相互のト リッブの伸びも大きい，実際に，適正容積率推計モデル で対象となる都区部の集計ネットワーク（有向 118 リン ク）において，道路交通センサス（H6）によって得られ る道路混雑状況を図4に，また現況の都市構造の分布を， 土地利用現況調査 ${ }^{16)}$ からグロス容積率によって表した もの在図 5 に示寸。

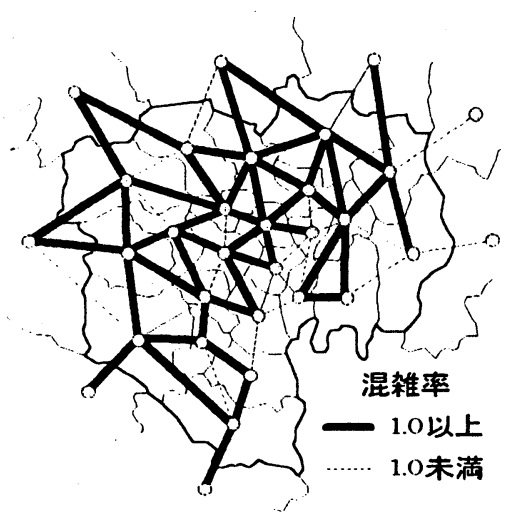

図 4 道路混雑状況

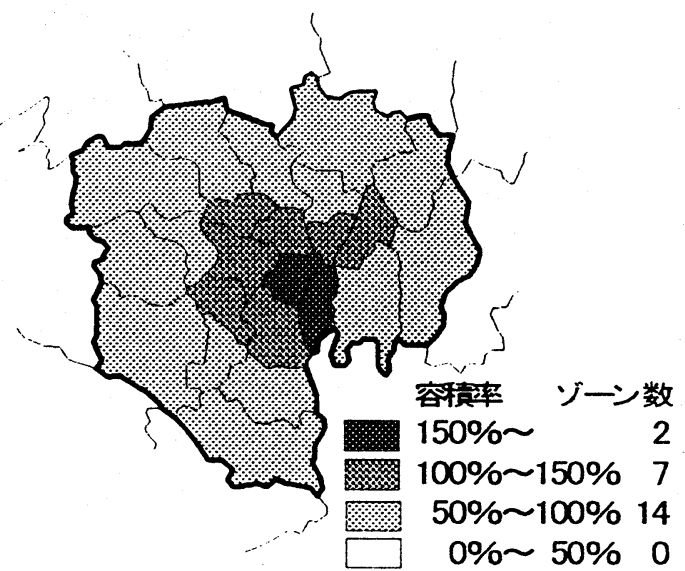

図 5 現状の容積率分布（1991）

道路混雑の現状を見てみると，東京都区部においては 終日平均混雑率が $134 \%$ となっており, 対象路線の約 7 割が混雑率 100\%を越えている. また東京都市圈内の区部 外地域での平均混雑率は $100 \%$ となっている.

また図 5 から，都心である千代田区・中央区に高い容 積率を示し，それを中心に容積率が分布して抢り，東京 の一極集中構造の様子が伺える.つまり，これまでの計 画で唱えられてきている多心型構造が必要だとされなが らも，現実では都心の集中は十分に抑制できなからたと いえる.

\section{(2)道路交通施設に対応した都市構造}

ここでは，既存の道路ネットワークにお!活適正な都 市構造を求めるとともに, 将来, さらに床を増加させる 際に, 道路負荷が小さくなるような都市構造を推計寸る.

（a）交通容量を最大限に使った場合の都市構造

これまで示した都区部の有向 118 リンクの道路容量に, 都市計画道路 (都市計画決定済み) が完成したと仮定し, その道路容量を加えたものを交通容量制約として，区部 内の容積率の最大化を行う。また混雑率を東京の当面の 目標である 1.25 と設定した（図6).

現状の容積率分布と比較寸ると, 適正值は総量的に現 況の 4 割程度と低い結果を示している.これは各リンク 間の道路容量が現在の交通需要に対して極めて低いこと に起因寸るが, 同時に都市内の道路容量の分布バターン が都市容量に対して効率的な配置になっていないことも 原因の一つとして挙げられる.

また，比較的高い容積率は環状六号線，山手線といつ たゾーンにドーナツ型に分布していることが分かる. 特 に豊島区，新宿区，港区，台東区，江戸川区といった 23 区の内側から外周区にか时て, 高容積率ゾーンが分布し ていることが加かる，一方で，千代田区，中央区といっ た都心部一の容積率配分は極めて低く割り当てられた。 つまり現在の一極型構造より, 新宿区，台東区といった 副都心を育成した多極型の都市構造の方が道路容量から 見ると，効率的であるということを示している. また， 総じて区部の西側区の方が東側に存在する区より大きな 
容積率を割り当てられており, 西高東低の都市構造の傾 向犸伺える。

ここで図 6 は，副都心構想に挙げられた新宿，渋谷， 池袋，上野・浅草，錦系町・亀戸，大崎地区そして臨海 副都心ひ 7 地区をも示している. 推計値と比較すると， 概して副都心ぶ位置するゾーンに，高い容積率が配分さ れているのぶ分かる．したがって，計画策定時において は鉄道網を考慮して打ち出された副都心構想であるが， 道路容量における視点からでも同様の都市構造の分布で 良いと言える。

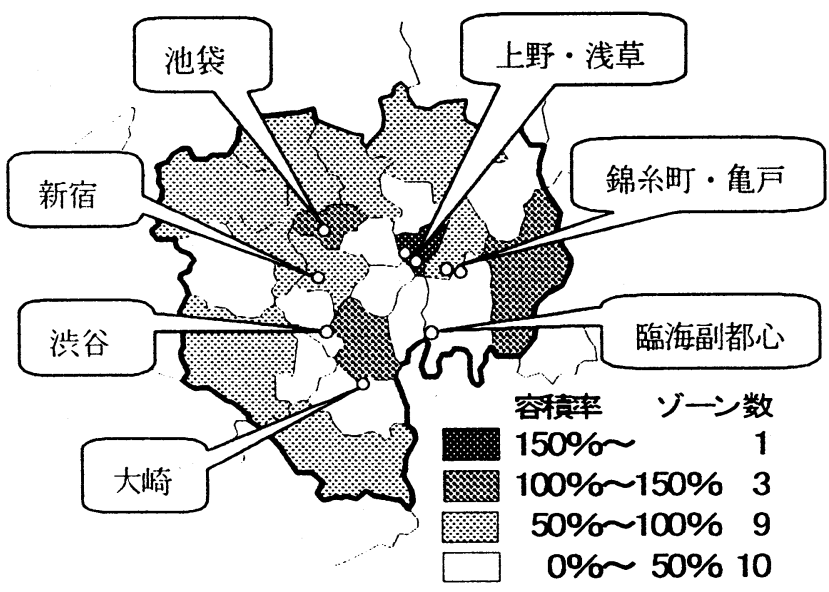

図6 混雑緩和の都市構造と副都心図

（b）增加可能な都市容量

（a）では，都市計画道路オ゙完成した状態で区部の道路 混雑を緩和した都市構造について検討した. それはあく まで一つの理想像として捉えるべきであり，今後の都市 成長を考える際には，いかに道路負荷を小さく寸るかが 問題である.ここでは, 既存の都市容量を是認した上で, さらに都市成長を行う際にどのゾーンに都市開発をする ことが，道路に現況以上の負荷をかけずに成長できるか を模索寸る. そこで, 目標混雑度として 1.25 を設定し, その混雑度までは許容できるとした場合の増加可能な都 市容量を試算する。 ただし増加可能容量が少ないリンク に関しては，混雑度を現況值まで許容した上で各ゾーン 間に 4 車線道路を新設して分析を行う（図 7).

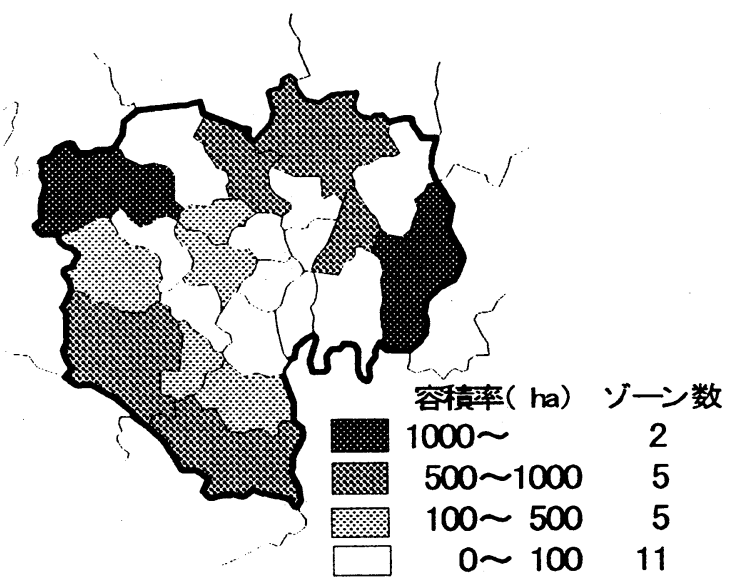

図 7 増加可能な都市容量の分布図
この結果, 東京 23 区全体では約 7,600ha の床沙増加可 能であることが分かった．また分布図を見ると，区部外 周区の効率性が明らかになった。つまり（a）でのシミ ュレーションと合犯せと，副都心の育成とともに，さ らに広域的な多心型都心構造が望ましいと言える。

\section{5. 結論}

本研究では簡便な交通／土地利用モデルを構築寸るこ とで，東京都区部において道路容量を考虑した適正容積 率を推計し，土地利用政策と比較・評価を行った。

シミュレーションの結果, 道路混雑のない都市構造は 都心の容積率が低く，豊島区・新宿区・台東区さりに外 周区は相対的に高い，多極型の都市構造であること流わ かった。これと，首都圈整備基本計画や東京都長期計画 において揭げられている政策を比較すると，概方副都心 構想と一致し，現況の政策の有用性が確かぬられた。

また，今後の都市開発に当たり道路負荷をか川なない゙ ーンを把握する事を試みた，その結果，練馬区・世田谷 区・大田区・北区・足立区・江戸川区と外周区に開発可 能なゾーンが位置していることが扔かった。

本研究において，今回の試算は道路容量の，に着目し て行っており，自動車交通に関してのみの評価を行って いるに過ぎない，区部の都市構造を検討寸る際には鉄道 等の他の交通機関を考慮寸ることが不可欠である。 また 交通需要予測に才いても，より現実的な経路選択の配分 を行うために，高速道路等の道路階層等も考虑したモラ゙ 儿改良が必要となる.

最後に, 本研究に対し土地総合研究所小ら研究助成志 いただきました，記して感謝の意を表します。

\section{【参考文献】}

1) Giuliano, G : RResearch policy and review 27. New directions for understanding transportation and land use $\rfloor$. Environment \& Planning A Feb 1989. v21. n2, p145(15) 2) Webster, F. V. : 「Urban land-use and transport intcraction : policies and models : report of the International Study Group on Land-Use/Transport Interaction (ISGLUTI)」, Avebury. cl988 3）柏谷增男, 朝倉康夫, 矢島徽也 : 「道路混椎緩和のための土地 利用誘導モデルに関寸研究」, 土木計画学研究·論文集. No.13, pp.247-256, 1996

4）森本章倫，中川義英：「道路容量加办大適正容皘率U設定に 関与石研究」，土木学会論文集, No.440//V-16, pp. 145-153, 1992 5）中條 賞，山川仁秋山哲男:「道路基盤から，双大適正上地 利用の算出について」，土木学会第 53 回年次学術講演会, pp.328-329, 1998

6) 西宮良一，中村 理，佐々木俊治:「東京都長期計画策定のた ぬの基磷的調查 一望ましい都市構造の分析一」, 土木計画学研 究・講演集, No.5, pp75-84, 1983

7) 川上秀光 : ‘東京の中心市街地動向と多心型都市構造論」，第 
21 回日本都市計画学会学術研究論文集, pp.13-18, 1986

8) 牛由 清:「首都圈け)分散政策シミュレーションー多極分散型 都市檴造老目指して一」、第 23 回日本都市計画学会学術研究論 文集, pp.79-84, 1988

9) 小根山裕之・大西博文: 環境負荷の小さい都市構造・交通体 系に関古ろ一考察」, 土木計画学研究・講演集, No.20(2), pp129-132, 1997

10) 杉田 浩, 鹿島 茂, 谷下雅義, 高嶋裕治 : 「東京都市圈に 打け万交通行動の地域特性分析と都市構造の評価に関文万研 究」, 土木計画学研究・講演集, No.21(2), pp.459-462, 1998 11) 川上秀光 [著], 計画論研究会 [編 : 「巨大都市東京の計画 論!, 彰国社, pp. 1990)
12）国土庁大都市圈整備局 : 「首都改造計画」，1985

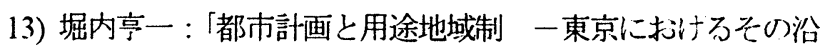
革と展望一」，pp.105-171, 1978

14）溝上章志・松井 寛・可知 隆: ‘日交通量配分に用いるリ ンクコストの開発」，土木学会論文集，第 401 号/IV-10, 99-107, 1989

15）建設省都市局都市交通調查室 :「平成 4 年度第 2 回全国都市 バーソントリップ調査報告書」, 1993

16) 東京都都市計画局:「東京の土地利用 平成 3 年東京都区部! 1993

17）東京都：「均衡のとれた東京の成長を目指して」，1991

18）日本都市計画学会 [編] :〔東京大都市圈」, 1992

\section{道路容量からみた東京都区部の都市構造の事後評価に関する研究}

吉田 真紀, 森本 章倫, 古池 弘隆

東京都市圈に执いて, 自動車交通の急激な増大が道路施設供給をはるかに上回り, 道路混雑の悪化を招いている. これを抜本的に解決する方法として土地利用規制, 特に容積率規制が挙げられる. 本研究では多極分散型の都市構 造を目指した東京の土地利用計画に対して，道路施設容量からみて適切であるか検討を行う.シミュレーション分 析の結果, 現況の容積率と理想值はかなりの隔たりはあるものの，計画目標としている都市構造は概ね道路混雑を 緩和させる都市構造と同様であることがおつかった。

An Evaluation of Urban Structure in Tokyo Wards in terms of road capacity

By Maki Yoshita, Akinori Morimoto and Hirotaka Koike

In Tokyo Metropolitan Area, the rapid increase of automobile traffic far surpasses the provision of road facilities. and the traffic congestion is worsening. One method to cope with this problem is the control of land use, especially the regulation of floor area ratio (FAR). In this study we examine if land use planning in Tokyo, which has the goal of the multi-nucleus urban structure. have corresponded with the road capacity. After the simulation study, although there are considerable gap between current FAR and permissible FAR, the planning urban structure is considered almost the same as a desirable structure alleviating the road congestion. 